\title{
Resultater ved fronten - brugen af effektstyring i dagtilbud
}

\author{
Caroline Howard Grøn
}

ph.d., adjunkt, Institut for Statskundskab, Københavns Universitet

Hvad sker der med resultatstyring, når det rammer velfærdsstatens yderste led? Denne artikel ser på, hvordan effektstyring, en variation over resultatstyring, er blevet omsat til handling i dagtilbud i Frederiksberg kommune. Artiklen viser, at selvom tiltaget blev formidlet ens til alle kommunens daginstitutioner, ledte det til meget forskellige handlinger i praksis. Hvor nogle pædagoger slet ikke gjorde noget for at implementerede effektstyring, var der også pædagoger, der på en lang række områder arbejde aktivt med tiltaget. De gjorde bare mange meget forskellige ting med det samme initiativ som referencepunkt. Variationerne i anvendelsen af effektstyring kan delvist forklares med graden af lokal ledelsesopbakning, den måde arbejdet $\mathrm{i}$ institutionen er organiseret på samt omfanget af konkurrerende dagsordner. Artiklen illustrerer, hvordan ét værktøj i praksis kan forvandles til mange forskellige styringsværktøjer.

\section{Indledning}

Resultatstyring startede sin indrejse i den danske offentlige sektor i 1980'erne, og som Mads Bøge Kristiansen illustrerede, har tækningen om resultatstyring udviklet sig over tid. Hvor vi i første del af temanummeret var interesserede i de lange linjer i tænkningen om resultatstyring, ser vi i denne del af temanummeret nærmere på anvendelsen af resultatstyring i praksis, og hvilke barrierer der er for implementeringen af resultatstyring. Hvor den foregående artikel så på både tale, beslutninger, handlinger og resultater (jf. Brunsson 2002 og Pollitt 2001) på det administrative niveau i kommunerne og søgte at forklare, hvorfor benchmarking bliver indført og opret- holdt, er ambitionen i dette bidrag at se på det yderste led af den offentlige styring; levering af velfærdsydelser. Også her finder vi brug af resultatstyring. Det er ikke længere kun politikområder, der er præget af let målelige ydelser, der arbejder med resultatstyring. Også både socialområdet (jf. Hansen Kristiansen \& Sørensen 2014), dagtilbudsområdet, som beskrives her, og en række andre „bløde“ områder arbejder med fokus på resultater, evidens og effekt. Netop fordi tænkningen bag resultatstyring er en anden end de fagligt dominerende paradigmer på disse velfærdsområder (jf. Grøn 2014), kan de være interessante at udforske, når vi er interesserede $\mathrm{i}$, hvilken betydning resultatstyring har i praksis. Dagtilbudsområdet er på den måde en såkaldt „least likely“ case for anvendelsen af resultatstyring i den danske offentlige sektor. Et område, hvor vi teoretisk ville forvente, at det ville være svært at styre på resultater af en lang række årsager. For det første er det svært at tilskrive ansvar for fx børns resultater i skolen alene (eller bare primært) til det dagtilbud de har modtaget. Teoretisk kender vi denne diskussion som problemer med agenternes „efficacy“ (Miller \& Whitford 2006) eller co-production (De Bruijn 2002). Derudover er dagtilbud et område, hvor det kan være svært at opstille specifikke mål for, hvad børnene skal have ud af dagtilbud, medmindre disse bliver meget abstrakte. Endelig har dagtilbud har en lang række komplekse mål, et fænomen også kendt fra andre typer af offentlige ydelser (Beck Jørgensen 2003, 20-21). Vi vil altså forvente at se resultatstyring $\mathrm{i}$ en meget udfordret form i denne case, og det vil give os et interessant indblik $i$, hvordan resultatstyring påvirker handling og resultater, når det bevæger sig ind på blødere velfærdsområder.

Det er vigtigt at se på, hvordan væsentlige styringsredskaber udvikler sig over tid på tale- og beslutningsniveauet, men som implementeringsforskningen siden Pressman og Wildavsky (1973) har gjort os opmærk- 
somme på, kan der være umådeligt langt fra politiske beslutninger til den faktiske implementering, der er essentiel for borgernes oplevelse af offentlig service. Det gør sig ikke mindst gældende på de store velfærdsområder, hvor borgernes oplevelse af service i stort omfang er afhængig af, hvordan den offentligt ansatte, de står over for, varetager sine arbejdsopgaver (jf. fx Le Grand 2003; Grøn \& Hansen 2014). I indledningen beskrev vi, hvordan institutionaliserede styringsopskrifter kan tage mange empiriske former. Det er altså endnu et argument for, at det kan være relevant at se på, hvordan resultatstyring omsættes til handling i det yderste led i styringskæden, hvis vi skal have en forståelse af styringsopskriftens virkning.

Dagtilbudsområdet er et godt eksempel på et stort velfærdsområde, hvor borgernes oplevelser af service hænger sammen med, hvordan markarbejderne agerer. Borgernes oplevelse af service formes for både børn og voksnes vedkommende i høj grad af, hvordan interaktionen med de ansatte i dagtilbud, pædagoger og pædagogmedhjælpere, opleves. Fysiske rammer, normer for bemanding spiller selvfølgelig en rolle, men medarbejdernes indsats er helt central.

Af de to àrsager bliver det interessant at undersøge, hvordan effektstyring påvirker handlinger og resultater på dagtilbudsområdet, og ikke mindst hvilke barrierer der kan identificeres for implementeringen?

I 2011 vedtog kommunalbestyrelsen i Frederiksberg Kommune, at kommunen skulle implementere effektstyring; et styringskoncept inspireret af resultatstyring, der lokalt blev givet navnet effektstyring. I Frederiksberg Kommunes version af effektstyring er den centrale styringsidé, at kommunens forvaltninger skal styre imod en række målsætninger opstillet af politikerne i kommunalbestyrelsen, og at de målsætninger, der defineres, er rettet mod de effekter, der ønskes for borgerne og samfundet (Frederiksberg Kommune 2011, 2). Dette defineres i modsætning til traditionelle styreformer, hvor der styres efter indsatsen. Derudover indeholder effektstyring en idé om, at indsatser skal tilrettelægges efter viden om, hvordan målsætninger bedst muligt opnås. Der skal løbende indsamles dokumentation, målinger, evaluering og feedback for at sikre, at de opstillede målsætninger nås. Denne information kan anvendes til at træffe kvalificerede politiske beslutninger om, hvordan kommunens midler skal prioriteres. Der er altså elementer af resultatstyring, som vi definerede det i temanummerets start. Der er fokus på opstilling af målsætninger og på at indsamle information til at belyse, hvorvidt mål nås. Endelig er ambitionen, at den information, der indsamles, kan bruges til beslutningstagning (Frederiksberg Kommune
2011, 3). Effektstyring blev implementeret på tværs af forvaltninger og således også på dagtilbudsområdet, og derfor er Frederiksberg Kommune en interessant case. Kommunens tilgang til effektstyring tager udgangspunkt i en „forandringsteori“ (se figur 1), der er en model for effektstyring udviklet af Rambøll, men som trækker på bl.a. evalueringslitteraturens brug af programteori (jf. fx Pawson \& Tilley 1997).

Artiklen vil i det følgende afsnit se lidt nærmere på casen, effektstyring i dagtilbud i Frederiksberg Kommune og de data, analysen af casen bygges på. Derefter introduceres en teoretisk diskussion af handlinger og resultater, effektstyring kan medføre. På den baggrund analyseres handlinger og resultater af effektstyring, og på baggrund af disse diskuteres barrierer for anvendelse af effektstyring. Endelig opsummeres artiklens fund.

\section{Effektstyring på Frederiksberg: casen, data og metode}

Casen: Effektstyring i dagtilbud på Frederiksberg ${ }^{1}$

I indledningen blev det kort defineret, hvad effektstyring betyder på Frederiksberg. Casen er imidlertid ikke hele kommunens anvendelse af effektstyring, men den lokale anvendelse på dagtilbudsområdet, der er underlagt Børn og Unge-direktøren. Derfor er det også væsentligt kort at se på, hvordan effektstyring er omsat på forvaltningsniveauet i dagtilbudsforvaltningen. Effektstyring er her omsat i en forandringsteori illustreret i figur 1. Forandringsteorien er udgangspunktet for arbejdet med effektstyring på dagtilbudsområdet.

Forandringsteorien læses fra højre mod venstre. I udgangspunktet finder vi to strategiske pejlemærker, hhv. skoleparathed og livsduelighed. De er politisk fastsat, og de gør, at effektstyring også ses som en måde at sikre politisk styring på. På den baggrund opstilles mål på mellemlagt sigt, eksempelvis at $95 \%$ af alle børn skal kunne koncentrere sig i 15 minutter. Mål på mellemlangt sigt er defineret i samarbejde mellem forvaltningen og institutionsledelserne. Resten af forandringsteorien er det op til institutionerne at udfylde, hvilket er en ret stor del af arbejdet. Dette er et bevidst valg, der er truffet for at signalere tillid til institutionsniveauet. Effektstyring på dagtilbudsområdet er tænkt som en blød form for resultatstyring, der kobles ikke incitamenter på styringsformen, i stedet er tanken. at effektstyring skal bidrage til en mere systematisk måde at tænke pædagogiske indsatser på og en større opmærksomhed blandt pædagoger og ledere om de overordnede mål for kommunens dagtilbud. Forandringsteorien lægger derudover op til løbende (kvantitative) evalueringer af, hvorvidt de tiltag, der gøres, har den ønskede effekt. 
Figur 1: Forandringsteorien²

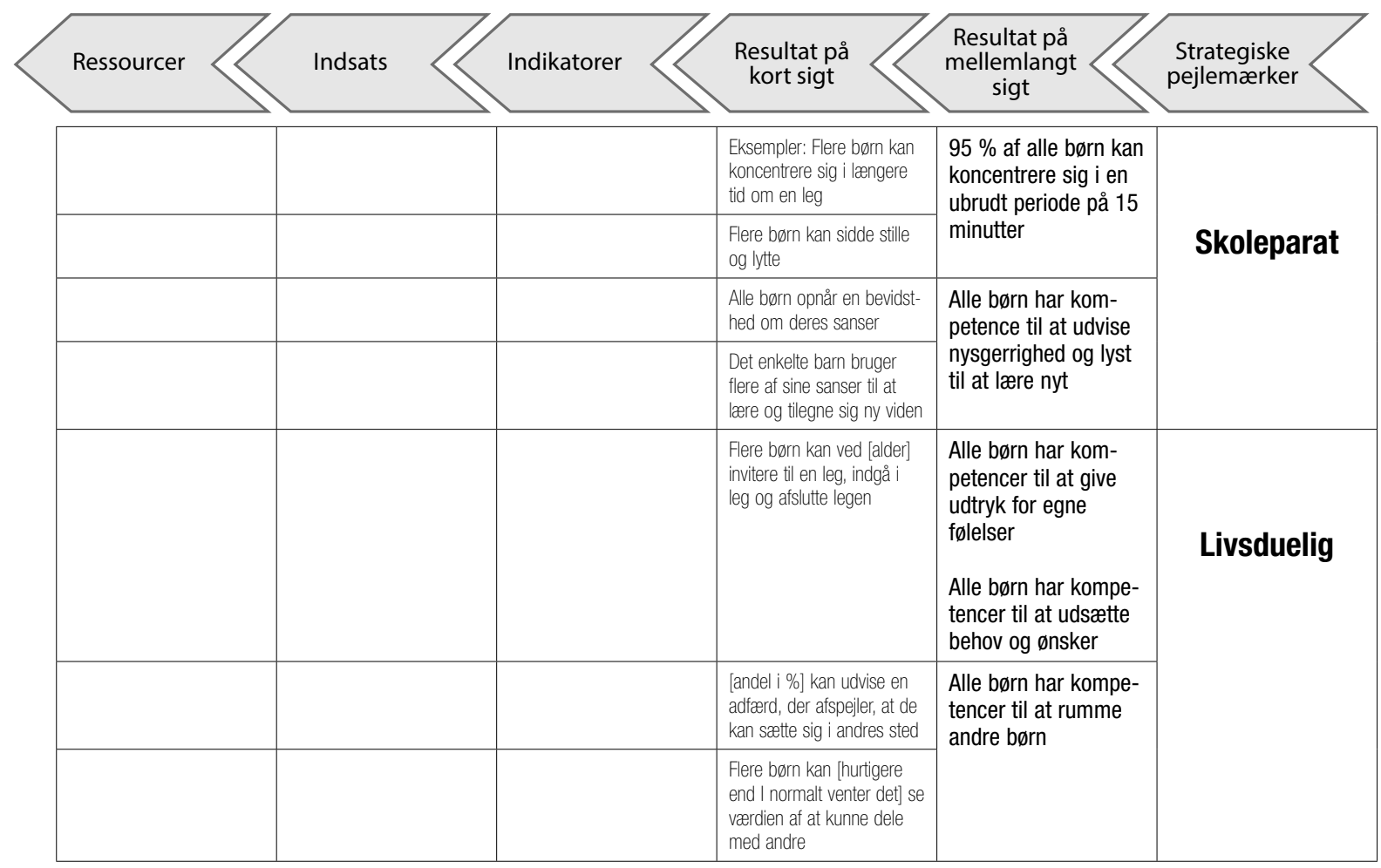

Der er ca. 54 institutioner i Frederiksberg Kommune. Institutionerne styres igennem fokusaftaler (en slags resultatkontrakter), og der afholdes månedlige møder mellem alle ledere af dagtilbud og dagtilbudschefen. Institutionerne i Frederiksberg Kommune er af varierende størrelse, fra 14 til 256 børn, og med et gennemsnitligt børnetal på 99. Det gør, at lederrollen kan variere ret meget fra institution til institution. Fælles for de institutioner, der har været repræsenteret i denne undersøgelse, er dog, at pædagogerne har meget stor frihed i planlægningen af det daglige arbejde, og at lederne spiller en relativt lille rolle. Oftest foretages planlægning på stueniveau eller i forhold til børnegrupper af jævnaldrende børn ( $f x$ 0-2 år eller førskolegruppe, 5-årige). I praksis er det derfor pædagogerne, der skal arbejde med effektstyring, hvis det skal omsættes i handling og resultater. Derfor er fokus i denne undersøgelse på, hvordan denne gruppe ansatte arbejder med effektstyring.

\section{Metode og datagrundlag}

Datagrundlaget for casestudiet er fokusgrupper med pædagoger ansat i institutioner i Frederiksberg Kommune. Arbejdet med effektstyring har været fulgt i to år og seks måneder, hvoraf pædagogerne har været inddraget i to år. Over de to år (2013 og 2014) har der været afholdt fem runder fokusgrupper. Antallet af grupper per runde samt de totale antal pædagoger har varieret. Denne artikel tager udgangspunkt i de to runder fokusgrupper, der er afholdt i 2014. Tabel 2 opsummerer datamaterialet.

Tabel 2: Data

\begin{tabular}{|l|c|c|}
\hline & Antal grupper & Antal pædagoger i alt \\
\hline $\begin{array}{l}\text { Runde 1, 2014 } \\
\text { (6. marts - 2. juni) }\end{array}$ & 5 & 16 \\
\hline $\begin{array}{l}\text { Runde 2, 2014 } \\
\text { (28. august - 8. oktober) }\end{array}$ & 4 & 14 \\
\hline
\end{tabular}

Interessen her er i, hvordan effektstyring påvirker handlinger og resultater. Pædagogernes anvendelse af effektstyring forandres over tid, og derfor er denne del af datamaterialet valgt ud. 2013 blev af mange anset som et år, hvor man skulle „øve sig“. Det forekommer altså rimeligt at antage, at den måde, effektstyring anvendes på i 2014, er et udtryk for en implementering, der om ikke er „færdig“, så i hvert fald fremskreden. I kodningen af data er der 16 unikke pædagoger på tværs af de to grupper. Nedenfor er disse pædagogers handlinger med reference til effektstyring kodet, og hver enkelt af de 16 er indplaceret i artiklens model. 
Der er både yngre og mere erfarne pædagoger repræsenteret i fokusgrupperne, hvor der desuden er en klar overvægt af kvinder, hvilket nok afspejler faget som sådant. Deltagerne i fokusgrupperne er uddannede pædagoger, eftersom de er målgruppen for effektstyring. Fokusgrupperne er sammensat af pædagoger fra institutioner, hvor institutionslederen har meldt institutionen til at deltage i projektet. Det betyder, at der må forventes en bias i data i retning af, at de institutioner, der arbejder mindst med effektstyring, er underrepræsenteret. ${ }^{3}$

Vi skal nu se nærmere på, hvordan handlinger og resultater teoretisk kan forstås i denne kontekst.

\section{Handlinger og resultater på baggrund af resultatstyring}

Som diskuteret i tidligere artikler kan organisationers output, jf. Brunsson (2002) og Politt (2001), forstås på fire niveauer. Organisationer kan tale, de kan træffe beslutninger, de kan handle, og endelig kan de opnå resultater. Som skrevet ovenfor afgrænser denne artikel sig til at se på, hvilke effekter resultatstyring kan have på hhv. handlings- og resultatniveauet.

Konkret er interessen her i at forfølge, i hvilket omfang indførelsen af effektstyring har ændret handlinger i de enkelte dagtilbud. Handlinger i Brunssons forstand er egentlig produktion, og det er klart, at når vi overfører sådan en tænkning til dagtilbud, så må definitionen af handling modificeres. Det, der grundlæggende er af interesse her, er, i hvilket omfang pædagogerne ændrer deres daglige praksis som følge af effektstyring. Det er klart, at sådan en praksisændring kan komme i mange forskellige former. Grundlæggende vil analysen af disse handlinger, eller praksisændringer anskues på to dimensioner: For det første, i hvilket omfang der er praksisændringer. For det andet vil analysen belyse, hvorvidt disse praksisændringer ligger i forlængelse af intentionerne med effektstyring eller tager form af ikke-intenderede konsekvenser. I den foregående artikel blev Moynihans anvendelsesformer (2009) præsenteret, og den tækning kan også finde anvendelse her, med visse modifikationer.

På den første dimension ser vi på omfanget af handlinger. Her kan vi forestille os, at effektstyring har fä effekter på handlingerne i dagtilbud. Moynihan (2009, 593) taler om, at brugen kan være passiv - at agenterne minimumsopfylder krav, men fx ikke bruger relevante data. Her kunne der fx være tale om, at dagtilbuddet foretager obligatoriske test, men ikke ændrer på praksis i øvrigt. I sådan et tilfælde er det klart, at det må være en empirisk sondring, hvor meget handling, der skal til, for at man overhovedet kan tale om handling. Der kan dog også være en reel mulighed for afkobling i Brunssons forstand (Brunsson 2002). Altså at handlingsniveauet slet ikke påvirkes af den megen „tale“ om effektstyring. Ikke mindst fordi kommunen har svært ved at overvåge, om effektstyring rent faktisk implementeres, og heller ikke har intentioner om det ud over en årlig fokusaftale med institutionsledere, hvor arbejdet dokumenteres. Men om det dokumenterede arbejde rent faktisk finder sted, er der ikke et ønske om at kontrollere. Det kan altså være, at der er pædagoger, der falder helt ud af modellen. I den anden ende af skalaen finder vi mange handlinger med reference til effektstyring. Her kan være tale om, at effektstyring anvendes som planlægningsværktøj i dagligdagen, eller at der foretages regelmæssige tests af børnene.

Den anden dimension vedrører som nævnt, hvorvidt anvendelsen ligger i forlængelse af intentionerne bag effektstyring eller ej.

Anvendelsen kan ligge $i$ forlangelse af intentionerne bag effektstyring på dagtilbudsområdet. Moynihan taler om purposeful anvendelse (Moynihan 2009, 593). Hvis vi vender os mod fx Røviks retorik, vil der være tale om enten et kopierende eller modificerende oversættelsesmodus (Røvik 2007, 308ff). Tanken er, at effektstyring enten leder til handlinger, der ligger i direkte forlængelse af intentionen med at indføre effektstyring, alternativt måske ikke helt præcist leder til de handlinger, der var intentionen, men at anvendelsen kan vurderes som bidragende til målet, om end i mindre målestok.

I den anden ende af kontinuummet bliver effektstyring brugt $i$ modsatning til intentionerne bag effektstyring. Det kan fx betyde, at effektstyring medfører helt andre mål, end det var intentionen, alternativt, at effektstyring har negative konsekvenser for det, der var målet med indførelsen. Her taler litteraturen om perverse effekter ( $\mathrm{fx}$ hos Moynihan 2009, 593; De Bruijn 2002, 17ff), fx hvis aktørerne er så opsatte på at opfylde mål, at de snyder for at opnå dem eller leder opmærksomheden væk fra andre også relevante hensyn, der ikke er målbare. I tilfældet her kunne det være, at centrale elementer i børnenes pleje og omsorg i dagtilbuddet ignoreres til fordel for at gøre dem skoleparate - et af målene opstillet af kommunen. Tilsvarende kan ikke-intenderede effekter, når vi ser på denne type af markarbejdere, også være negative motivationseffekter (jf. litteraturen om motivation crowding, $\mathrm{fx}$ Frey \& Jegen 2001).

I en given empirisk case vil de to dimensioner af handlinger kunne anskues som et koordinatsystem, illustreret i figur 2. Tanken her er, at der vil være tale om grader af overensstemmelse/uoverensstemmelse med intentionen, der typisk vil være en totalitet af de mange forskellige handlinger, effektstyring medfører. 
Figur 2: Handlinger som konsekvens af effektstyring

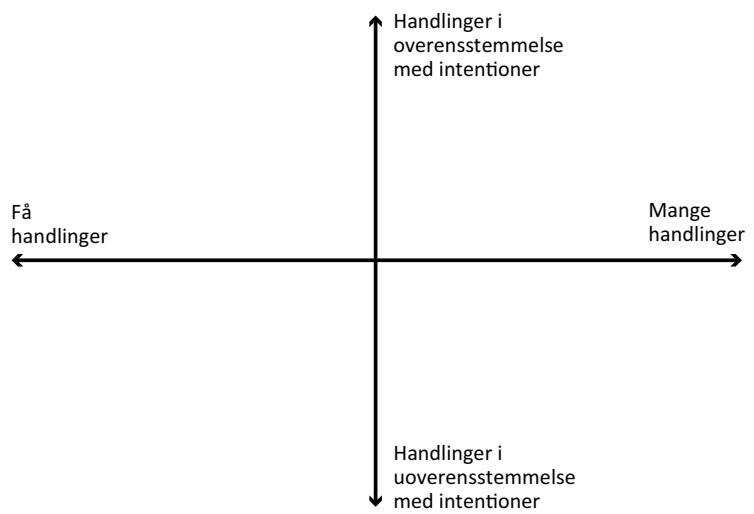

Politt (2001) tilføjer resultater til Brunssons tredeling af organisatorisk output. Resultater forstås på den måde, at de handlinger, organisationen foretager, rent faktisk også medfører den effekt, der var intentionen (outcome). Resultatniveauet kan operationaliseres til, hvorvidt dagtilbuddene igennem arbejdet med effektstyring lykkedes med at gøre børnene i dagtilbud mere skoleparate og mere livsduelige.

På den baggrund er vi nu klar til at se på, hvordan effektstyring leder til handlinger og resultater i dagtilbud i Frederiksberg Kommune.

\section{Handlinger og resultater: Anvendelsen af effektstyring i dagtilbud}

Hvordan handler pedagogerne?

Som beskrevet ovenfor kan de handlinger, effektstyring medfører, anskues på to dimensioner: Hvorvidt de ligger i forlængelse af intentionen med effektstyring eller ej, og i hvilket omfang der overhovedet er tale om handlinger. Figur 3 giver et overblik over placeringen af de 16 forskellige pædagoger, der tilsammen deltog i de to sidste runder fokusgrupper. Igennem en kodning af den enkelte pædagogs anvendelse af effektstyring og omfanget af anvendelsen har jeg placeret dem på de to dimensioner.

En metodisk note er på sin plads. Vurderingerne er selvfølgelig mine subjektive vurderinger på baggrund af pædagogernes udsagn. ${ }^{4}$ Den præcise placering i forhold til akserne kan diskuteres. Placeringen skal ses som relativ, A placerer sig anderledes end B. Ambitionen med figur 3 er at give et grafisk overblik over spredningen i de handlinger, effektstyring medfører. I det næste afsnit kvalificeres dette overblik med eksempler på enkeltes faktiske praksis (disse pædagoger er markeret med fed i modellen). Det gøres delvist for at give en dybere forståelse af spredningen i de handlinger, effektstyring medfører, men også som et forsøg på at gøre kodningen af enkeltindividers anvendelse transparent.
Figur 3. Handlinger som konsekvens af effektstyring

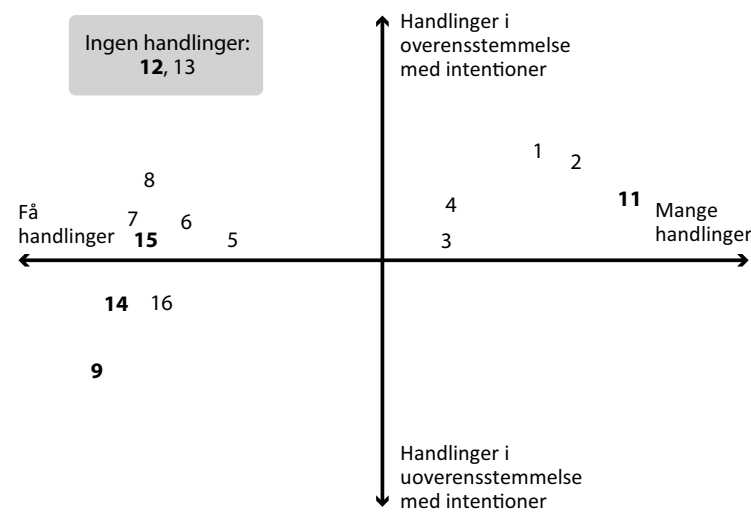

Figuren illustrerer, at pædagogerne groft sagt klumper sig sammen tre steder i figuren og at der derudover er to pædagoger, der falder ud af modellen. Der er en gruppe, der handler relativt meget på baggrund af effektstyring og i overensstemmelse med intentionerne. Her finder vi fem af de 16 kodede pædagoger, dvs. lidt under 1/3. En anden gruppe placerer sig til venstre herfor på x-aksen. De handler relativt lidt på baggrund af effektstyring, og det varierer lidt, om det kan siges at være svagt i overensstemmelse med intentionerne eller svagt i uoverensstemmelse med intentionerne. I denne gruppe finder vi fem pædagoger. Endelig finder vi en gruppe, der heller ikke handler særlig meget på baggrund af effektstyring, men hvor det primært sker i uoverensstemmelse med intentionerne. Her finder vi tre pædagoger. Når vi ser på denne gruppe, er det vigtigt at understrege, at de ikke-intenderede konsekvenser, der kan identificeres i materialet, ikke primært vedrører klassiske problemer med resultatstyring, som $\mathrm{fx}$ målforskydning. I stedet er der tale om, at pædagogerne giver udtryk for, at effektstyring er demotiverende, enten fordi pædagogerne ikke gør det, og det giver dem dårlig samvittighed, eller fordi det anses for at være unødvendigt bureaukrati, der tager opmærksomheden væk fra kerneydelsen. Der er altså tale om ikke-intenderede effekter på et lidt andet analytisk niveau end fx målforskydning.

Overblikket illustrerer altså, at størstedelen af de pædagoger, der deltager i fokusgrupperne, handler på baggrund af effektstyring, men at det langt fra er noget, der fylder meget i deres hverdag. Dertil kommer, at flertallet af de undersøgte pædagoger faktisk handler i overensstemmelse med intentionerne i effektstyring, men at de fleste gør det i en lav grad. En model over den måde, effektstyring er tænkt at skulle virke (let tilvirket i forhold til temanummerets indledning), kan illustrere brugen, set på tværs af pædagogerne. 
Figur 4: Elementer af effektstyring

\begin{tabular}{|c|c|c|c|}
\hline Mål defineres & Indsats & $\begin{array}{l}\text { Evaluering af indsats } \\
\text { i forhold til mål }\end{array}$ & $\begin{array}{l}\text { Revurderet } \\
\text { indsats }\end{array}$ \\
\hline $\begin{array}{l}\text { Målene er centralt } \\
\text { definerede, alle } \\
\text { institutioner har } \\
\text { lavet lokal tilpasning, } \\
\text { de fleste steder er } \\
\text { de i bevidstheden } \\
\text { hos pædagogerne. }\end{array}$ & $\begin{array}{l}\text { Mange forskellige } \\
\text { indsatser; indsatser } \\
\text { både i forhold til } \\
\text { børnene (aktiviteter), } \\
\text { og i forhold til } \\
\text { pædagogerne } \\
\text { (fx observationer). } \\
\text { Enkelte laver ingen } \\
\text { indsatser. }\end{array}$ & $\begin{array}{l}\text { Evalueringer hos en } \\
\text { del af pædagogerne, } \\
\text { få laver kvantitative } \\
\text { evalueringer, flere } \\
\text { laver kvalitative } \\
\text { evalueringer. }\end{array}$ & $\begin{array}{l}\text { De fleste påpeger, } \\
\text { at de bliver mere } \\
\text { reflekterede, når de } \\
\text { arbejder med } \\
\text { effektstyring, } \\
\text { men effekter } \\
\text { ud over dette er } \\
\text { svære at } \\
\text { identificerer. }\end{array}$ \\
\hline
\end{tabular}

I det næste afsnit skal vi se nærmere på, hvilke handlinger der i praksis kommer ud af effektstyring, når vi ser nærmere på pædagog $11,12,14,15$ og $9 .^{5}$ De er valgt ud fra to kriterier, delvist for at illustrere spredningen i modellen, delvist fordi deres praksis giver indblik i argumenter, der er relevante for en større del af populationen.

\section{Handlinger i praksis - hvad gør de, når de handler?}

Pædagog nr. 11 bruger effektstyring i ret stort omfang. Fire gange om året testes børnene på en række parametre på baggrund af løbende aktiviteter. Et af indsatsområderne vedrører legekompetencer, et aspekt af livsduelighed, og her har pædagogerne selv været med til at udvikle den målingsmetode, der anvendes. Pædagogen forklarer: „Så vi har faktisk lavet legemålingen om, [... så] vi både evaluerer $p a$, hvordan de er $i$ stand til at tage initiativ og udvise engagement, og altså deltage, fastholde fokus, afslutte legen. Der har vi simpelthen fäet lov at lave den om."

Mere konkret tager målingen form af en observation af børnenes leg. Pædagogen forklarer: „Og så satter vi os ned og observerer. Vi observerer kun. Vi går ikke ind. Og så gør vi det $i 10$ minutter til et kvarter for hver gruppe, og så skriver vi ned, hvordan går det. Og så går vi alle børnene igennem. [...] Men faktisk har det vist sig at vere ekstremt informativt [...], vi kan i hvert fald godt se, hvor vi skal hen og arbejde med børnene [...]. Jeg vil sige, vi måler børnene i virkeligheden. [...], så siger [vi] hov der er et barn her, der har brug for ekstra laring eller ekstra inddragelse i legen og ekstra understottelse til at lere at lege sammen og lege rettet ud mod de andre og ikke lege parallelleg og alle de der [ting]. Så altså på den måde synes jeg, det har varet effektivt."

Pædagogens brug af effektmåling påvirker hendes handlinger i ret stort omfang. Hvis vi ser på, i hvilket omfang effektstyring anvendes i overensstemmelse med intentionen, må konklusionen også være, at anvendelsen ligger ret tæt op ad intentionen med indførelsen af effektstyring. Effektstyring bliver anvendt til at kvalificere det pædagogiske arbejde. Imidlertid oplever pædagogen udfordringer på to områder. For det første i forhold til anvendelsen af de kvartalsvise målinger af børnene. På spørgsmålet, om det er muligt at adskille forskellige faktorers indflydelse på den udvikling, børnene gennemgår, svarer pædagogen: „Det er rigtig svert. [...] jeg ved ikke, hvad jeg helt måler $p a ̊$, når jeg måler. Jeg har egentlig haft det problem hele tiden, vil jeg så sige. Altså jeg synes, det er vanskeligt at finde ud af, hvad det er, at jeg måler, når jeg måler [men...] ungerne synes det en festlig leg, og foraldrene ser tilbørligt imponerede ud." Dertil kommer, at pædagogen oplever, at dokumentationsdelen af målingerne er et stort problem for både hende selv og hendes kolleger. Målingerne foretages på papir, men pædagogerne har svært ved at finde tid til at registrere målingerne elektronisk. De løbende målinger af børnene er mest noget, der gøres, fordi det er et krav oppefra, hvorimod de løbende (kvalitative og kvantitative) observationer af børnene opfattes som nyttige af pædagogen. En anden udfordring, pædagogen oplever, vedrører medarbejdernes ejerskab: „Jeg tror det for mange har det endt med at foles, som om det her det er hat og briller", siger hun i udgangspunktet, men forklarer derefter, hvordan pædagogerne af egen drift har modereret de skemaer, de bruger, når de tester børnene. Fx har pædagogerne tilføjet alder til skemaet for at gøre skemaets informationer mere brugbare. Så på trods af, at testen kan opfattes som „hat og briller“, så har pædagogerne alligevel engageret sig i arbejdet med værktøjet og forsøger at få det til at give mening. Dertil kommer, at ledelsen i institutionen over tid har insisteret på, at pædagogerne anvender målingerne. I 2013 rapporterede pædagogen, at langt færre af hendes kolleger udførte tests, men i 2014 er alle ifølge pædagogen kommet med i ar- 
bejdet med effektstyring. Pædagog 11's oplevelse af, at de kvalitative observationsteknikker kan give et "nyt" blik på børnene i børnegruppen, går igen hos en række af de øvrige pædagoger ( $\left.f_{x} 1,2,14,15\right)$. På den måde bliver effektstyring omsat til en form for handling, der nok ligger et stykke fra den kvantitative og kausale logik, der er iboende tænkningen om resultatstyring, men som et langt stykke hen ad vejen anvendes i overensstemmelse med intentionerne bag værktøjet - at sikre øget faglig refleksion blandt pædagogerne.

Pædagog nr. 12 placerer sig i den modsatte ende af figuren. Hun tilhører til gengæld den gruppe af pædagoger, der bruger effektstyring meget, meget lidt. Hun forklarer: „Ja, altså vi arbejder jo ikke med effektstyring på vores institution, [...] det gor vi ikke. Vi har ikke noget med nogle skemaer, vi udfylder eller noget, og vi snakker aldrig om det. Vi havde lidt sidste år, men ellers har der ikke varet noget." Pædagog nr. 12 handler meget lidt på baggrund af effektstyring. Men hvor nogle af de andre pædagoger til tider kan opleve, at det er demotiverende (fx nr. 9, 10 eller 16) at vide, at man bør arbejde med effektstrying, når man ikke gør det, så oplever nr. 12 ikke dette problem: „Altså, jeg laver jo de ting, som jeg plejer at gøre med børnene, ikk'. Og jeg synes [ikke], det har nogen indflydelse på fagligheden, hverken hos mig eller mine kolleger [...] Og jeg synes heller ikke, det er demotiverende for nogen af os, fordi det er ikke sädan i vores bevidsthed $i$ hverdagen, vel. Altsa vi prover at rette ind i forhold til det, vi synes i forhold til bornene og sådan som, bornene udvikler sig, og stille nogle flere krav og andre på de aktiviteter og sådan noget, ikk, så det ligesom folger med bornenes udvikling, og sådan har vi altid gjort. Og vi har ikke mål på det, så vi kan ikke se ... og sammenligne."

Pædagog nr. 14 er et eksempel på en pædagog, der faktisk i en periode har arbejdet med effektstyring, og som også i en tidligere runde (3. runde fokusgrupper, november 2013) havde fundet en tilpasset måde at arbejde med resultatstyring på. Imidlertid er pædagogen og hendes kolleger gået i stå med arbejdet: „... vi er faktisk gået lidt i stå på vores stue ... fordi vi skal jo skrive ned hver gang. Der SKAL gå en fra og observere, der slet ikke hjalper med noget ... der kun sidder og skriver og kigger." På den baggrund vurderes der p.t. at være relativt få handlinger, der relaterer sig til effektstyring. Effektstyring spiller ikke nogen særlig rolle i deres dagligdag på stuen, men det er ikke helt forsvundet ud af pædagogernes bevidsthed. "Øhh ... jo, jeg ved ikke, om man kan kalde det effektstyring eller hvad man kalder det, men man er selvfolgelig mere bevidst om, hvad man selv gor i forhold til børnene [...]men vi tenker da på det meget stadigvak. Lidt som en dårlig samvittighed, synes jeg." Her finder vi et eksempel på, at pædagogerne oplever effektstyring som en kilde til dårlig samvittighed. Egentlig ville hun gerne arbejde mere med effektstyring og har i en tidligere runde også talt positivt om det, men hun oplever, at rammerne for hendes daglige arbejde gør det svært. Så selvom, der er elementer af tænkningen, hun anvender (selvom hun også påpeger, at det måske er svært at sige, at det er effektstyringens skyld), så vurderes brugen af effektstyring at være svagt $\mathrm{i}$ uoverensstemmelse med intentionerne bag effektstyring. Intentionen var næppe at give pædagogerne en følelse af dårlig samvittighed og utilstrækkelighed.

Pædagog nr. 15 bruger effektstyring, men i en version, som er ret omfortolket i forhold til udgangspunktet. Hun er medtaget her, fordi den måde, effektstyring er omfortolket på i forhold til udgangspunktet, er illustrativ for, hvordan mange af de pædagoger, der arbejder lidt med effektstyring, anvender det. Imidlertid er beretningen om praksisfortællinger nedenfor hentet fra første runde fokusgrupper i 2014. I anden runde var pædagogen helt holdt op med at tale om effektstyring, og derfor er pædagogen placeret, som hun er, i modellen ovenfor.

I stedet for de løbende kvantitative optællinger anvender pædagog nr. 15 i stedet praksisfortællinger som „registreringsværktøj": „Vi [lavede] det om til, at man lavede praksisfortallinger $i$ stedet for.. og det er ogsa det, der er meningen nu, at vi skal lave praksisfortallinger over det her [...]. Altså som måleredskab på effektstyring [...] i stedet for nogle afkrydsningslister, og det synes jeg giver mening. Altså fordi så bliver det et padagogisk redskab, som vagter noget."

Praksisfortællingerne kan vedrøre en række aspekter, men tænktes for pædagog nr. $15 \mathrm{i}$ høj grad ind i forhold til inklusionsdagsordnen, der også fylder meget i kommunens institutioner. Praksisfortællingerne er en måde at sammenfatte kvalitative observationer af kollegernes arbejde med en børnegruppe på. Efter at en pædagog har observeret, har pædagogen tid til at gå fra børnegruppen og skrive praksisfortællingen med det samme: „Og det er det, jeg har varet glad for, og det var også det, der var blevet sat tid af, at når man så havde lavet denne her praksisfortalling - når nu vi kom hjem fra en skovtur og lavede praksisfortalling - så havde man fri til at gå ind og skrive den. Altså... med det samme.. uden at blive afbrudt.. og det synes jeg var enormt rart, så man ikke har sådan en masse ting liggende, man ikke fär gjort, og det kommer for langt vak, at man rent faktisk fär det gjort." Rammerne om praksisfortællingerne opleves altså som gode af pædagogen.

Praksisfortællingerne indeholder som nævnt observationer, pædagogen forklarer: Altså jeg har lige skrevet en, [...] hvor jeg sà var inde sammen med en anden, som satter nogle gamle sanglege i gang, hvor jeg så skal sidde og observere, hvor jeg kan se, at der er en pige, som er til stede - jeg skriver, hvornair hun har øjenkontakt med de voksne f.eks., som laver noget og hun kigger op og smiler til den padagog, 
hun er tryk med... med hvad hun gør, når de så fysisk skal rore ved hinanden... altså... hun gor det, at hun lagger handerne der eller hun trakker sig, eller hun kigger ned $i$ gulvet. [...] det er jo det, jeg ser [...] Sådan noget... det kan man jo så tale om. Hvis man så diskuterer det alle sammen sammen efterfolgende, så vil man jo måske have nogle forskellige idéer til, hvordan man fär åbnet op eller hvornår hun skal have lov at trakke sig, og hvornår hun skal have lov at vere en del af gruppen og... på den måde synes jeg, det er rart at fä fokus, at man kan sige inden man går ind "det er mig, der skal observere i dag - er der nogen born, I har lyst til, at jeg kigger pà?" ".

Observationer og praksisfortællinger er et værktøj, pædagogen finder nyttigt, fordi det hjælper til at fokusere på særlige indsatsområder, der efterfølgende kan diskuteres i pædagoggruppen. Det er samtidig klart, at praksisfortællingerne ikke i så høj grad refererer til de to centrale værdier i effektstyring, livsduelighed og skoleparathed. Der er et stærkt element af, at pædagogerne i højere grad fokuserer på enkelte børn ud fra en mere generel betragtning, og som måske også handler om deres generelle fornemmelser for børnenes trivsel end et mere snævert fokus på de politisk definerede mål. På den baggrund vurderes pædagogen at handle på baggrund af effektstyring på en måde, der i relativt lav grad er i overensstemmelse med intentionen. I forhold til omfanget af handlinger, der er konsekvenser af effektstyring, er det ikke helt klart, hvor tit, der skrives praksisfortællinger, men det er i hvert fald mindre end en gang om ugen, og opgaven går også på tur mellem pædagogerne.

Pædagog nr. 9 er den sidste pædagog, vi skal se nærmere på. Hun er udvalgt, fordi hun er den, der igennem fokusgrupperne har afrapporteret størst uintenderede konsekvenser. Disse konsekvenser er primært fokuserede på pædagogens oplevelse af motivation og mening: „... altså det er ligegyldighed fra min side, og det er også det, jeg siger til dem, der stresser helt vildt meget over det... „lad nu var' med at stresse over det, fordi om en måned hedder det noget andet". Altsà vi folger bare med [...]. Det er bare, det, der er udfordringen, det er det der med at holde fast, og det sker bare ikke i det her felt."

Pædagogen beretter om, at effektstyring i hendes institution nu er afløst af inklusionsdagsordnen: „... nu er der kommet noget nyt med inklusion og nu handler alting om inklusion. [...] Men ordet effektmåling, det bruger vi ikke rigtig mere." Pædagogen beretter, som hun i tidligere fokusgrupper har berettet i relation til effektstyring, at det er svært for medarbejderne at få ledelsen til at melde klart ud, hvorfor de skal gøre de ting, de skal gøre. I relation til inklusionsdagsordnen beretter hun: „Alle skal lave iagttagelser og skrive ned og alt muligt [...], og det skal aflevereres hos lederen om fredagen, og jeg aner ikke, hvad det skal bruges til. Dét kunne måske motivere den enkelte medarbejder, ikk. Jeg aner ikke, om det har noget med effektstyring eller inklusion eller hvad ...". Pædagogen arbejder stort set ikke med effektstyring mere og oplever, at effektstyring er en blandt mange dagsordner, der ruller ind over feltet, som sjæxldent bliver formidlet af ledelsen, og som hurtigt afløses af noget andet. Man kan spore en vis kynisme hos pædagogen, når det kommer til styringsværktøjer.

\section{Kan vi forstå, hvorfor de handler så forskelligt?}

Som analysen gør klart, er der tydelige forskelle i, hvordan pædagogerne ændrer deres praksis med reference til effektstyring. Hvis vi sammenligner de pædagoger, der placerer sig i første kvadrant, med pædagogerne i andet og tredje kvadrant, kan fokusgrupperne så sige noget systematisk om forskellene? Hvis man ser på tværs af pædagogerne i første kvadrant springer fire ting i øjnene, de har til fælles, og hvor, på et eller flere parametre, de adskiller sig fra de øvrige pædagoger:

1) Ledelsesopbakning: Både 1, 2 og 11 beretter om tydelig ledelsesopbakning og om, at ledelsen, selv i de situationer, hvor der har været modstand mod effektstyring blandt pædagogerne, har insisteret på, at effektstyring skulle implementeres. For pædagog nr. 11 er det interessant at gå tilbage i de tidligere fokusgrupper, hvor man faktisk kan spore en tydelig modstand mod effektstyring. Pædagogen har også i 2013 berettet, at meget få $\mathrm{i}$ institutionen havde implementeret de kvartalsvise målinger. Imidlertid er ledelsen blevet ved med at insistere på, at det skal gøres. Og i sidste ende har det medført, at implementeringen er slået igennem $\mathrm{i}$ institutionen.

2) Tid: Centralt for både de pædagoger, der arbejder meget med effektstyring, og dem, der ikke gør det, er spørgsmålet om tid. Pædagogerne oplever, at deres sparsomme planlægningstid skal bruges på en lang række opgaver. Fælles for de institutioner, der arbejder forholdsvis meget med effektstyring er, at ledelsen har afsat tid specifikt til effektstyring, og det er blevet meldt ud, at effektstyring har forrang over andre aktiviteter, pædagogerne også bør foretage sig.

3) Kompetencer: Det er kendetegnende for de institutioner, der arbejder systematisk med effektstyring, at en eller flere centrale medarbejdere har påtaget sig rollen som oversætter, ud over den oversættelse lederen leverer. De, der arbejder med effektstyring, har typisk lavet en lokal tilpasning, der har fået effektstyring til at fremstå meningsfuldt for pædagogerne.

4) Ingen konkurrende dagsordner: Det er tydeligt i datamaterialet, at når nye dagsordner rammer institutioner, $\mathrm{fx}$ en politisk prioritering af inklusion ( $\mathrm{fx}$ 
pædagog 6 eller 14) eller institutionssammenlægninger (fx pædagog 7 ), stor personaleudskiftning ( $f x$ pædagog 5) eller andet på institutionsniveauet, så flyttes opmærksomheden mange steder væk fra effektstyring, eller tingene „slås sammen“. Det er svært for pædagogerne at rumme flere parallelle indsatser oven i deres øvrige opgaver.

De pædagoger, der i mindre grad arbejder med effektstyring, kommer typisk fra institutioner, hvor en eller flere af disse faktorer er fraværende.

\section{Resultater af effektstyring}

Effektstyring har fungeret i dagtilbud i Frederiksberg Kommune siden starten af 2013, og det er endnu svært at sige noget meget definitivt om, hvorvidt børnene på Frederiksberg er blevet mere livsduelige og skoleparate af indsatsen. I første runde fokusgrupper i 2014 blev pædagogerne bedt om at vurdere betydningen af effektstyring for hhv. børnenes skoleparathed og deres livsduelighed. På en skala fra -10 (stor negativ effekt), over 0 (ingen effekt) til +10 (stor positiv effekt) er pædagogerne blevet bedt om at vurdere effekten på de to parametre. Gennemsnitsvurderingen for skoleparathed er 1,7 , mens den for livsduelighed er 1,9. Disse tal skal selvfølgelig tages med et vist forbehold pga. de få besvarelser, og gennemsnittet for livsduelighed påvirkes meget af en enkelt outlier, der er har en markant mere positiv evaluering end de øvrige. Alt i alt må pædagogernes vurdering siges at være, at der nok er en svagt positiv effekt af effektstyring på børnenes livsduelighed og skoleparathed, men at den meget godt passer med indtrykket fra analysen ovenfor: Effektstyring har langt fra revolutioneret pædagogernes handlinger, og tilsvarende er resultaterne af effektstyring, i pædagogernes optik, også forholdsvist begrænsede.

\section{Konklusion}

Ambitionen i denne artikel var at belyse, hvordan effektstyring påvirker handlinger og resultater på dagtilbudsområdet i Frederiksberg Kommune, og at identificere barrierer for implementeringen. Analysen viste, at effektstyring leder til meget forskellige handlinger i institutionerne, men at langt de fleste handler relativt lidt med reference til effektstyring. En konklusion, der må bestyrkes, når mulige selectionbiases i udvælgelsen af deltagerne i fokusgrupperne indtænkes. ${ }^{6}$ Når vi vurderer, hvorvidt handlingerne sker $\mathrm{i}$ overensstemmelse med intentionerne bag effektstyring, kan vi konstatere, at de fleste handler i overensstemmelse med intentionerne, men at det sker i en „minimumsversion“, hvor effektstyring for langt de fleste primært betyder større refleksion, men ikke markant ændret praksis eller systematiske evalueringer af indsatser. Hvis vi ser på resultaterne, må disse stadig tages med visse forbehold. Pædagogerne afrapporterer en svagt positiv effekt, hvilket stemmer meget godt overens med analysen af deres handlinger. Det er selvfølgelig vigtigt her at understrege, at de to delanalyser trækker på informationer fra de samme informanter, pædagogerne, og vurderingen af resultater måske havde set anderledes ud, hvis ledere af dagtilbud, forvaltningen eller forældrene var blevet spurgt.

I forhold til at identificere barrierer for anvendelsen af effektstyring, blev fire positive karakteristika udpeget, der understøtter implementeringen, og det blev påpeget, at de pædagoger, der ikke arbejder særligt meget med effektstyring er ansat i institution, hvor en eller flere af disse elementer mangler. Først og fremmest blev det klart, at arbejdet med effektstyring afhang af ledelsens opbakning til projektet. Lederens rolle som både oversætter og katalysator for den fortsatte anvendelse var central. Dertil kom, at lederen også skal afsætte ressourcer til implementeringen, implementering kræver, at medarbejderne får tid til at arbejde med opskriften og får mulighed for at tage ejerskab til det. Den anden side af ligningen er, at der også skal være medarbejdere, der griber chancen for at tage dette ejerskab. Endelig kræver det ro at implementere noget nyt. Hvis der er mange dagsordner, der konkurrerer om medarbejdernes opmærksomhed, er det ikke overraskende, at den dagsorden, der ligger dem fjernest, får mindst opmærksomhed.

Endelig gjorde casen det tydeligt, hvor vigtig konteksten er for implementering af styringsopskrifter. Materialiseringen af den abstrakte institution resultatstyring udfoldede sig i denne case som en tilpasning til pædagogernes kontekst. En radikal omformning af den ide, vi diskuterede $\mathrm{i}$ indledningen, men også en omformning, der er foretaget $\mathrm{i}$ en række skridt fra Rambølls forandringsteori over kommunens valg af implementeringsstrategi til lokale forskelle fra dagtilbud til dagtilbud. Casen illustrerer på den måde, hvordan resultatstyring som koncept kan være en lang række forskellige ting i praksis, men også hvordan det kan være svært at holde konkrete materialiseringer af konceptet op på de generelle forventninger, man kan have til, hvad resultatstyring skal levere. Måske er det ikke rimeligt at forvente, at resultatstyring leverer, hvad det lover (jf. diskussionen i indledningen), når resultatstyring kan være så mange forskellige ting? 


\section{Litteratur}

Brunsson, N. 2002, The organization of hypocrisy: talk, decisions, and actions in organizations, 2. udg., Copenhagen Business School Press, København.

de Bruijn, H. 2002, Managing Performance in the Public Sector, Routledge, London.

Frederiksberg Kommune 2011, Effektstyring i Frederiksberg KommuneHvorfor og hvordan?, Frederiksberg Kommune, Frederiksberg.

Frey, B.S. \& R. Jegen 2001, 'Motivation crowding theory', Journal of economic survey, vol.15, no. 5, pp. 589-23.

Grøn, C.H. 2014, 'Effektstyring i felten', i CH Grøn, HF Hansen \& MB Kristiansen (red.), Offentlig styring. Forandringer $i$ krisetider, Hans Reitzels Forlag, København.

Grøn, C.H. \& H.F. Hansen 2014, 'Medarbejderne, borgerne og Brugerne: Styrede og medstyrende', i CH Grøn, HF Hansen \& MB Kristiansen (red.), Offentlig styring. Forandringer i krisetider, Hans Reitzels Forlag, København.

Hansen, H.F., M.B. Kristiansen \& E.M. Sørensen 2014, 'Resultat- og Evalueringsstyring i en krisekontekst', i C.H. Grøn, H.F. Hansen \& M.B. Kristiansen (red.), Offentlig styring. Forandringer $i$ krisetider, Hans Reitzels Forlag, København.

Jørgensen, T.B. 2003, 'Værdier og den offentlige sektor', i T. Beck Jørgensen (red.), På Sporet af en Offentlig Identitet - Verdier i Stat, Amter og Kommuner, Aarhus Universitetsforlag, Aarhus.

Le Grand, J 2003, Motivation, Agency and Public Policy: of knights and knaves, pawns and queens, Oxford University Press, Oxford.

Miller, G.J. \& A.B. Whitford 2006, 'The Principal's Moral Hazard: Constraints on the Use of Incentives in Hierarchy', JPART, vol. 17, pp. 213-233.

Morgan. D.L. 1996, 'Focus Groups', Annual Review of Sociology, vol. 22, pp. 129-152.

Pressman, J.L. \& A. Wildavsky 1973, Implementation: How Great Expectations in Washington Are Dashed in Oakland; Or, Why It's Amazing that Federal Programs Work at All, University of California Press, California.
Moynihan, D.P. 2009, 'Through A Glass, Darkly: Understanding the Effects of Performance Regimes', Public Performance \& Management Review, vol. 32, pp. 592-603.

Pawson, R. \& N. Tilley 1997, Realistic Evaluation, SAGE Publications ltd, London.

Pollitt, C. 2001, 'Convergence: The Useful Myth?', Public Administration, vol. 79, pp. 933-947.

Røvik, K.A. 2007, Trender og Translasjoner. Ideer som former det 21 århundrets organisasjon, Universitetsforlaget, Oslo.

\section{Noter}

1. Faktuelle informationer er fremkommet i korrespondance med forvaltningen.

2. Her er det væsentligt at holde sig for øje, at forandringsteorien ikke er en teori i den gængse samfundsvidenskabelige sprogbrug, men at teori, som begrebet anvendes her, viser tilbage til forandringsteoriens forståelse af teori.

3. For en diskussion af bias og selektionskriterier i dannelse af fokusgrupper, se (Morgan, 1996).

4. Denne vurdering bliver yderligere kompliceret af, at enkelte faktisk ændrer adfærd mellem den første og anden fokusgruppe anvendt her. I de tilfælde er det anvendelsen i den sidste af de to grupper, der afrapporteres.

5. Det er tilfældigt, at pædagogerne numerisk næsten kommer i rækkefølge. Numrene er tilskrevet pædagogerne i tilfældig rækkefølge, afhængigt af hvornår de optræder i udtræk af kodningen af transskriberingerne af fokusgrupperne. Der er altså ingen systematik i, hvem der har hvilket nummer.

6. Som skrevet ovenfor har lederne meldt pædagogerne til at deltage i fokusgrupper. Vi må forvente, at de ledere, der forventer mindst aktivitet i forbindelse med effektstyring i deres institution, vil være tilbageholdende med at melde deres pædagoger til en undersøgelse af effektstyring. Vi må derfor forvente, at bias i data overestimerer anvendelsen sammenlignet med hele populationen af institutioner på Frederiksberg. 